\title{
An Overview of the Development of Music Education in China's Normal Universities in the First Half of the 20th Century
}

\author{
Yu Xiang \\ School Music and Dance, Qujing Normal University, Qujing , 655011, Yunnan, China
}

152142418@qq.com

Keywords: Normal college music education; The first half of the 20th century; Development path

\begin{abstract}
The first half of the 20th century was a half-century of continuous exploration of the Chinese music education "look at the world and establish a foothold in the mainland. "The school song has opened the way for China to learn western music education. In the following decades, it continuously learns from Western and Japanese music education systems to build a systematic music education system in China. In this half-century, although the pace of music education in normal colleges is bleak, it has made remarkable achievements.
\end{abstract}

\section{The Development of Music Education in Normal Universities in the First Two Decades of the 20th Century}

China's school music education can be traced back to the Morrison School. It was relocated to Hong Kong in 1842 and opened music classes. This has also become the beginning of the development of modern school music education. Since then, a number of private schools, colleges, and halls have been established, and music classes have been set up and are taught by Western musicians. Since the "Hundred Days Reform" in 1898, represented by Kang Youwei and Liang Qichao, some intellectuals in China have begun to promote or engage in school music education, such as Shen Xingong, Zeng Zhiji, Cai Yuanpei, Yan Shi, Wang Guowei, etc. At the same time, the number of schools established by the Chinese people has gradually increased, and most music classes are opened, which indicates that China's school music education has entered a period of self-development [1].

In the 28th year of Emperor Guangxu of Qing Dynasty, the establishment of the Normal College of Peking University became the earliest higher normal school established in China. Its establishment marked the beginning of the education of higher normal education in China. [2]Twenty-nine years of Guangxu in the late Qing Dynasty, The issue of music education was mentioned in the "Constitution of the Guiding School" promulgated by the Qing government. In the thirty-three years of the Qing dynasty, in the "Constitution of the Women's Normal School of the Zouding Normal School" and "The Constitution of theZouding Girls' Primary School" promulgated by the Qing government, China's first time in the government's document stipulated that music lessons should be included in the school curriculum. Under the historical background of the reform of the reform, the bourgeois democratic revolution has continued to grow and develop. With the birth of a new school, the "Yue Songs" lesson has emerged. As the main content of aesthetic education, music education is valued by normal schools at all levels, and people have high enthusiasm for this new thing. [3]The earliest formal normal teacher music education in China can be traced back to the Southern Liangjiang formal Normal School (the predecessor of the Nanjing Higher Normal School) in the early 20th century, Beiyang Normal School in the north, and the Tianjin Music Gymnasium Training Center. They recruit arts students with a three-and-a-half year educational system. They are divided into preparatory and undergraduate programs. The courses offered include piano, vocal music, music scores, and music books. The three schools provided teachers who have received formal music education for the provinces of North and South, which also opened the prelude to the development of music education in China's higher normal schools. Beijing Normal University's predecessor, the Beijing Higher Normal School, also opened music songs in its curriculum in 1912. In 1916 and 1917, they respectively set up early music classes and 
advanced classes. Zhejiang First Normal University, Hunan Higher Normal School, Shandong Provincial First Normal School, Sichuan Higher Normal School, Jinghai Women's Normal School and other school set up respectively music subjects such as vocal music, chorus, music, composing lyrics, and piano. These schools became the explorers of music education in the early normal universities. It is worth mentioning that the Ministry of Education promulgated the Regulations for Advanced Normal Schools and the Curriculum Standards for Higher Normal Schools in 1913, which included the songs as a compulsory subject for the preparatory subjects. The content includes music theory and singing, This shows that the music education in higher normal schools has received a certain amount of attention.

\section{The Development of Music Education in Normal Colleges from 1919 to 1930}

The new culture movement around 1919 had a far-reaching impact on China's education. The school paid more attention to aesthetic education. In order to meet the needs of teachers at primary and secondary schools at that time, some higher normal schools established music subjects one after another, Private Shanghai Normal College and National Beijing Women's Higher Normal School are the most representative schools. the Private Shanghai Specialist Normal School funded by Liu Zhiping, Feng Zikai, and Wu Mengfei, was established in June 1919 and divided into two categories: the higher normal school and the ordinary normal school. The purpose of the higher normal education is to cultivate teachers' resources for normal teachers and middle schools. Music is a very important specialty in its Higher Teacher Education course. There are skills courses such as piano, violin, and traditional musical instruments such as Erhu. Theoretical lessons such as harmony, composition, music theory, etc. The school has trained a large number of outstanding talents for Chinese music education such as Tang Xueyong, Qian Juntao, Qiu Wangxiang, and Shen Binglian. The National Beijing Women's Higher Normal School established music and sports special subjects for three years under the educational efforts of music educators and composers Xiao Youmei and Zhao Yuanren, and later separated from physical education subjects to set up special music subjects. According to the "Music Journal" in the sports music grouping method published in June 1921, the curriculum of music subjects can be seen:(1) Theory courses: Ordinary Music Theory (20 hours), General Acoustics and Applied Acoustics (160 hours), Alignment Method (40 hours), Music History (40 hours), Acoustics (20 Hours), Stylistics ( 40 hours), musical instrument (20 hours), composition method ( 80 hours), and song method (80 hours). (2) Technical classes: Piano (120 hours), Piano practice (1440 hours), Solo (240 hours), Chorus (240 hours), Music score and rhythm practice (120 hours), Conduct (40 hours). [4]The opening of the above courses includes most of the content that music students should master, and even comparable to the current standards for the opening of music education courses in normal universities. This also sets a good example for the start-up development of the music education major in China's higher normal schools. Women's schools also attach great importance to students' musical art practice, regularly hold student concerts and teachers' teaching and reporting concerts. The results of the school's teaching can be seen in the "Order of the Seventh National Concert of the National Women's Normal University in Beijing" published in the fifth issue of the "Music Quarterly" in 1925. There are 13 programs include solo and joint performances by composers such as Schumann, Haydn, Beethoven and Debussy, The traditional Gu Yue lute solo "Cold magpies Competition for plum blossoms, The green is embellished by flying flowers". Hole flute solo"hunjianglong", Xiao Youmei's chorus works "Asking", "Morning Song", "The Returning Crow", "Music Section Level Song", Yang Zuxi's chorus song "Mei Yu" and "New School Song" and etc. In October 1928, the university merged with the National Peking University to establish the Music Department of the Women's College of Arts and Sciences. This became the first official and regular professional music department of the Higher Normal School in our country's history.

\section{The Development of Music Education in Teachers Colleges from 1930 to 1949}

In the early days of the Nanjing National Government, higher normal education did not receive 
enough attention, and music education was even more so. The National Peking Normal University did not have a music department. Music subjects existed only as a physical education subject. In 1932, the Third Plenary Session of the Fourth Session of the Kuomintang made the relevant resolution about higher teacher education. This has changed the status of neglected education in the normal universities. The government hopes to adopt resolutions to integrate the existing resources for higher teacher education so that it will be more in line with the purpose of teacher training in the middle of the curriculum. The private Guangzhou Conservatory of Music, which first dean is Ma sicong, pioneered a teacher education program with a two-year academic system, with the aim of training primary and secondary school teachers. The opening courses mainly include theoretical courses such as music theory, music appreciation, composition, acoustics and skills classes, singing, piano, and Sightsinging and ear training class. After that, Jimei Normal School, Chongqing Women's Normal School, Jilin Higher Normal School, Fujian Provincial Music College Education Training Course and South China Women's College of Arts and Sciences set up musical specialties for the purpose of cultivating music teachers in primary and secondary schools respectively. When the War of Resistance Against Japan broke out in 1937, the school education in the country was greatly affected. The lack of teachers was one of the core issues. To solve this problem, the Ministry of Education of the Nationalist Government promulgated the Regulations of the Teachers College in July 1938, and decided to set up a special Teachers College , In order to specifically train middle school teachers. [5]In 1939, the "Department of Required and Elective Courses for Teachers' Colleges" was enacted, and the courses were divided into compulsory and elective courses. Music classes were taken as a compulsory course for all teachers' colleges. [6]In the 1940s, many colleges and universities across the country opened the Music Teacher's Department, which included comprehensive universities, teachers' colleges, and professional music schools. In 1940, the Fujian Provincial College of Music was established. It established a specialized teacher training program in the school system. This has also become one of the schools in the history of professional music colleges that set up the normal department earlier. In addition to teaching music theory and skills and cultivating specialized music talents, it also includes the training of teachers in primary and secondary schools. The school has trained a large number of musicians and music educators such as Ye Lin, Wang Peiyuan, Yang Minwang and Sha Hankun for our country. The colleges and universities that set up music departments or music majors in the 1940s included the National Women's Normal College Chongqing Music Department (1940. 11), Hubei College of Education School of Music Specialized Course (1941. 7), Music Department of Peking Normal University (1942), Three-year Normal College of Chongqing National Academy of Music (1943. 1), Northwest Music Institute Teachers' College (1943), the Music Department of National Hubei Normal University (1944. 1), the Music Department of Changbai Normal University (1946. 8), the Specialis Music department of Jiangxi Provincial Sports Teachers College(1946. 8), the Specialist Music department of Taiwan Provincial Teachers College (1946. 10)the Three year specia Teacher Training Course of Shanghai Music Academy, the Specialist Music department of Hunan Music Academy.

\section{References}

[1] Z. Y. Liu. The general situation and prospect of music education in teachers colleges in China [J]. Journal of Tianjin Conservatory of Music. 2001 (3).

[2] Y. Y. Cui. History of Teacher Education in China [M]. Shanxi Education Press. 2006. First Edition. P. 33-34.

[3] J. Xu. A preliminary study of school songs in the early 20th century [J]. Journal of Xiangnan University. 2007(4).

[4] the Music, and Sports Grouping Method of Beijing Women's Higher Normal School[J]. Music Magazine Editorial Department, 1921, 2 (5. 6).

[5] S. Y. Wu. Yan Guohua. Comparison of Chinese and Foreign Education History [M]. Jinan: Shandong Education Press. 1997: 746. 
[6] H. X. Li. Republic of China Education History [M]. Shanghai: Shanghai Education Press 1997: 666-667. (In Chinese)

[7] Yu D, Peng L. When does Inferring Reputation Probability Countervail Temptation in Cooperative Behaviors for the Prisoners' Dilemma Game? [J]. Chaos, Solitons \& Fractals, 2015, 78: 238-244. 